\title{
Plasma-arc Remelting of Steels and Superalloys*
}

\author{
By Tatsuo FUJIWARA,** Koshi KATO,** Kiyoo ONO** and \\ Hiroyuki YAMADA**
}

\section{Synopsis}

The feature of plasma-arc remelting and the quality of plasma-arc remelted steels and superalloys were investigated by using an originally designed PPC (Plasma Progressive Casting) furnace with water-cooled copper mould of a $110 \mathrm{~mm}$ diameter and a maximum $150 \mathrm{~kW}$ power source.

The results obtained are as follows:

(1) It was possible to control the solidification structure of the PPC ingot. By selecting a relatively slow melting rate against a given plasma power, the metal pool became very shallow and flat, so that columnar crystals grew nearly vertical.

(2) The hot workability, based on the Gleeble test, of a solidificationcontrolled PPC ingot with vertical columnar crystals was superior to that of VAR ingot.

(3) No chemical composition change was observed on $\mathrm{Ti}, \mathrm{Al}, \mathrm{Mn}$, etc., and deoxidization could be made in the PPC process. As the deoxidizing mechanism, the $\mathrm{C}-\mathrm{O}$ reaction and the removal of the $\mathrm{Al}_{2} \mathrm{O}_{3}$ type oxide inclusions were considered.

(4) The smoothness of the ingot surface was comparable to that of ESR ingot, though some differences were observed among the steel grades.

(5) The distribution of alloying elements in a PPC ingot and its mechanical properties were almost same as those of the VAR ingot.

\section{Introduction}

Recently, with the rapid advance of industry, the specialty steels of good qualities are now in great demand. The remelting process is considered the best way to produce such steels. Various remelting processes have already been developed but new and better processes are still being developed. Nowadays, high reliable, high quality steels for such as jet engine materials, bearing materials used for the super-express trains in Japan, etc. are produced by the remelting processes. Four available remelting processes are widely applied to the commercial production. The merits and demerits of these processes are listed in Table 1 .

The processes of Vacuum Arc Remelting (VAR) and Electroslag Remelting (ESR) with the consumable electrode have been industrialized relatively early. VAR and ESR were developed at the early stage mainly in USA and USSR, respectively. Both processes are now widely used and many large scale furnaces are installed in many countries. On the other hand, the processes of Electron Beam Remelting (EBR) and Plasma Arc Remelting are the non-consumable electrode type.

They are well investigated in DDR ${ }^{5)}$ and USSR, ${ }^{2-4)}$ and much efforts to improve these are now made. We can see only a few papers on EBR of steels, but according to Förster, ARDENNE, DDR, there are already 3 to 4 furnaces working in steel plants which have the $1200 \mathrm{~kW}$ power source and can make a $800 \mathrm{~mm}$ diameter ingot.

Plasma-arc remelting is not used for industrial production except in USSR. Except in USSR, there are only 3 furnaces in the world known for the experimental use; ours, Fried Krupp GmbH's' (F. R. Germany almost the same power source as our own) and Schlienger Inc.'s one ${ }^{1)}$ (USA, $600 \mathrm{~kW}$ ).

It is well known that there are many industrial and experimental plasma-arc remelting furnaces in USSR, ${ }^{7,8)}$ one of which has maximum $1800 \mathrm{~kW}$ power source with 6 plasmatrons. ${ }^{2)}$ They are used for remelting of highly clean ball bearing steels, electromagnetic alloys, high nitrogen stainless steels (produced by using $\mathrm{N}_{2}$ as plasma gas), $\mathrm{Ni}$ and $\mathrm{Ti}$.

In 1973, we originally designed and installed a plasma-arc furnace with water-cooled copper mould

Table 1. Comparison of various remelting processes

\begin{tabular}{|c|c|c|c|c|}
\hline \multirow{2}{*}{ Features } & \multicolumn{4}{|c|}{ Remelting process } \\
\hline & PPC & EBR & VAR & ESR \\
\hline Remelting atmosphere & reduced/high pressure & high vacuum & vacuum & $1 \mathrm{~atm}$ \\
\hline Kind of atmosphere & $\mathrm{Ar}, \mathrm{He}, \mathrm{H}_{2}, \mathrm{~N}_{2}$, etc. & - & - & air, $\mathrm{Ar}$ \\
\hline Dependence of power against melt rate & independent & independent & dependent & dependent \\
\hline Control of solidification & possible & possible & difficult & difficult \\
\hline Refining by slag & possible & impossible & impossible & possible \\
\hline Degas $(\mathrm{N}, \mathrm{H})$ & slight & considerable & slight & no \\
\hline Deoxidation & considerable & considerable & considerable & not so good as others \\
\hline Reduction of tramp element ( $\mathrm{As}, \mathrm{Sn}, \mathrm{Pb})$ & slight & slight & slight & no \\
\hline Progressive solidification & better & good & good & good \\
\hline Hot workability & better & better & good & better \\
\hline
\end{tabular}

* Originally published in Tetsu-to-Hagané, 63 (1977), 2224, in Japanese. English version received May 31, 1978.

** Central Research Laboratory, R \& D Division, Daido Steel Co., Ltd., Daido-cho, Minami-ku, Nagoya 457. 
at our Central Research Laboratory. Its first aim was to study the remelting of steels and the second one, the melting of the reactive metals like Ti directly from the sponge-like raw materials.

We started this work with the maximum power source of $100 \mathrm{~kW}$, and in 1974 it was increased to $150 \mathrm{~kW}$. The main characteristic of the plasma-arc remelting is that the remelting rate and plasma power can be independently controlled.

In the present work, it was studied what good effects can be obtained upon the steel qualities from the characteristics of the plasma-arc remelting. Furthermore, the fundamental experiments were also made to develop the large scale furnace with multiple plasma-torches.

In the present paper, we mainly describe the quality and the characteristics of the plasma-arc remelted steels.

\section{Scheme of Plasma Arc Furnace and Its Operation}

Figure 1 shows the scheme of a new plasma-arc furnace installed, which we call PPC (Plasma Progressive Casting) furnace thereafter. A transfer type plasma-torch ${ }^{12)}$ was set vertically just above the mould and the raw material for remelting was fed into the furnace chamber through the simple seal-device. The water-cooled copper mould was combined with the movable bottom plate, which was withdrawn progressively according to the growth of an ingot. The furnace chamber was evacuated to the reduced pressure at the order of $10^{-3}$ Torr by a rotary and a mechanical booster pump, and then argon gas was supplied to $1 \mathrm{~atm}$. Remelting was made under argon

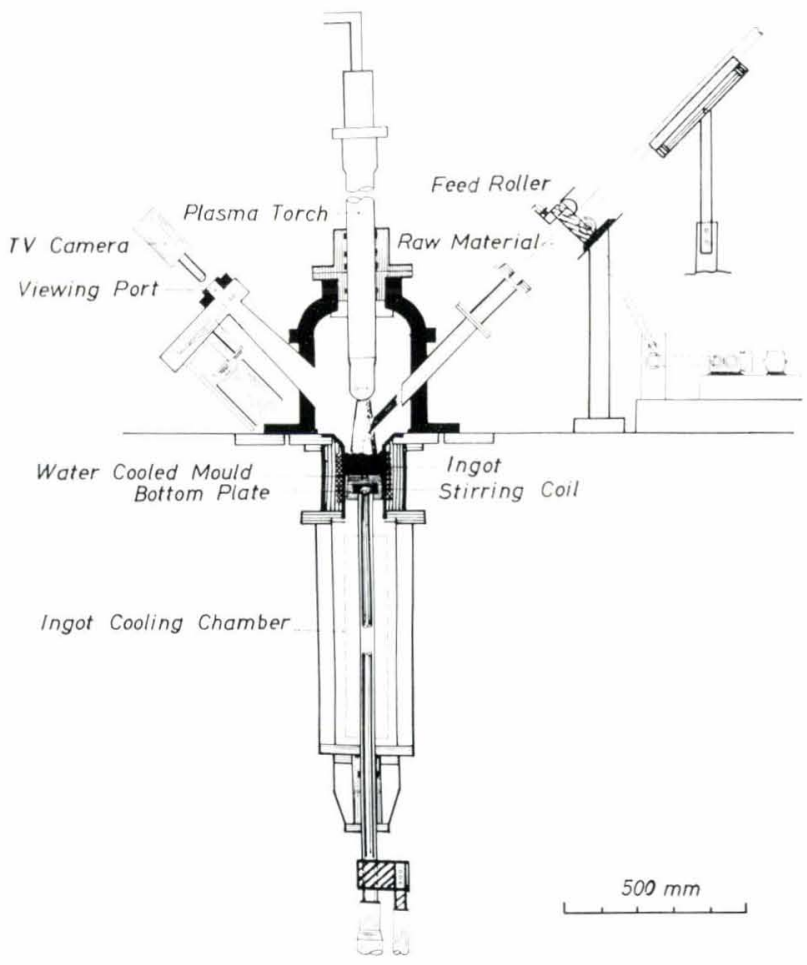

Fig. 1. Scheme of Plasma Progressive Casting (PPC) furnace atmosphere of 1 atm with continuous supply of argon gas. The argon gas as a plasma gas from the torch was flowed out through the leak valve of the furnace. Liquid Ar with the dew point below $-65^{\circ} \mathrm{C}$ was used. The furnace was remotely operated by watching the TV monitor.

The power source of $150 \mathrm{~kW}$ could supply electric current up to $1800 \mathrm{~A}$. The mould diameter was 110 $\mathrm{mm}$ and the maximum ingot had $600 \mathrm{~mm}$ length of about $45 \mathrm{~kg}$ weight. The raw material remelted was a $28 \sim 31 \mathrm{~mm}$ dia. $\times 1500 \sim 2000 \mathrm{~mm}$ length bar, which was welded with other one by TIG welding during melting without interrupting it.

We did not measure the temperature of the metal pool. It may vary dependently on the plasma power and the melting rate. Indeed by the observation of remelting, it was seen that over the $85 \mathrm{~kW}$ power input, the ripple of the pool surface was formed and the splash became violent. Judging from the conditions of the pool surfaces and the metal droplets falling from the bar, the temperature of the metal pool centre could be estimated as $1600^{\circ}$ to $2000^{\circ} \mathrm{C}$ in the range of 65 to $100 \mathrm{~kW}$ power.

\section{Experiments}

The steels used in the experiments were as follows: INCO718, A286, SUJ3 (AISI 52100) and SKDll. The $30 \mathrm{~mm}$ diameter bars for remelting were prepared by direct rolling or forging of the ingots premelted by various processes mentioned below and these were descaled.

The preliminary melting processes to produce the bars were as follows:

INCO718: VI (Vacuum Induction) + VAR, which were supplied by Teledyne Allvac Inc. in USA, or PI (Plasma Induction) melting only

A286: $\quad$ PI melting

SUJ3: $\quad$ Electric Arc Furnace melting followed by degassing

SKD 1 1: Air Induction melting

Only the bars of the PI melted INCO718 were directly produced by pouring the melt into the steel pipes. The chemical compositions of these bars are listed in Table 4 together with those of the remelted ingots. The plasma power, as shown in Table 2, were varied in the range of 65 to $100 \mathrm{~kW} \mathrm{(950}$ $1430 \mathrm{~A})$.

Furthermore, the melting rate was also varied to examine its effect upon the ingot soundness and quality. Argon flow rate was 50 to $70 \mathrm{~N} / / \mathrm{min}$. The melting rates were set by changing the rotating speed of the feeding roller for the bars for remelting. The examined ingots were $107 \mathrm{~mm}$ diameter, 300 to 400 mm length and 20 to $30 \mathrm{~kg}$ weight.

The followings were examined on the ingots: the macrostructure, the change of the chemical compositions before and after remelting and the segregation, the change of the shape, size distribution and composition of the oxide inclusions, the hot workability, 
and the mechanical properties. Furthermore, to examine the shape and the depth of the metal pool during $\mathrm{PPC}$ remelting, $\mathrm{Fe}-\mathrm{W}$ alloy was added into the metal pool and immediately the plasma power was turned off for rapid solidification. To compare with these ingots, the same examination was also made by the VAR ingot remelted in the $100 \mathrm{~mm}$ diameter mould (ingot weight was 10 to $15 \mathrm{~kg}$ ).

\section{Results and Discussion}

\section{Characteristics of Plasma-arc Remelting}

\section{Surface Appearance of Ingots}

The surface appearances of the PPC ingots of INCO718, A286 and SUJ3 remelted under the similar conditions are shown in Photo. 1. The INCO718

Table 2. PPC remelting conditions

\begin{tabular}{|c|c|c|c|c|}
\hline Alloy & No. & $\begin{array}{l}\text { Power } \\
(\mathrm{kW})\end{array}$ & $\begin{array}{l}\text { Av. amp. } \\
\text { (A) }\end{array}$ & $\begin{array}{c}\text { Melt rate } \\
\quad(\mathrm{kg} / \mathrm{h})\end{array}$ \\
\hline \multirow{5}{*}{ INGO718 } & I-2 & 72 & 1000 & 15.5 \\
\hline & $\mathrm{I}-3$ & 54 & 800 & 13.6 \\
\hline & I-5 & 65 & 1040 & 18.2 \\
\hline & I-6 & 65 & 1040 & 22.9 \\
\hline & $\mathrm{I}-7$ & 100 & 1380 & 29.0 \\
\hline \multirow{3}{*}{ A286 } & A-2 & 65 & 1040 & 15.6 \\
\hline & $A-3$ & 65 & 1040 & 23.5 \\
\hline & A-4 & 100 & 1380 & 28.6 \\
\hline \multirow{3}{*}{ SUJ3 } & $J-2$ & 65 & 1000 & 17.2 \\
\hline & $J-3$ & 65 & 1000 & 19.1 \\
\hline & $J-4$ & 85 & 1220 & 22.7 \\
\hline \multirow{3}{*}{ SKD11 } & $\mathrm{S}-2$ & 65 & 1000 & 15.7 \\
\hline & S-3 & 65 & 1000 & 18.5 \\
\hline & $\mathrm{S}-4$ & 85 & 1220 & 22.7 \\
\hline
\end{tabular}
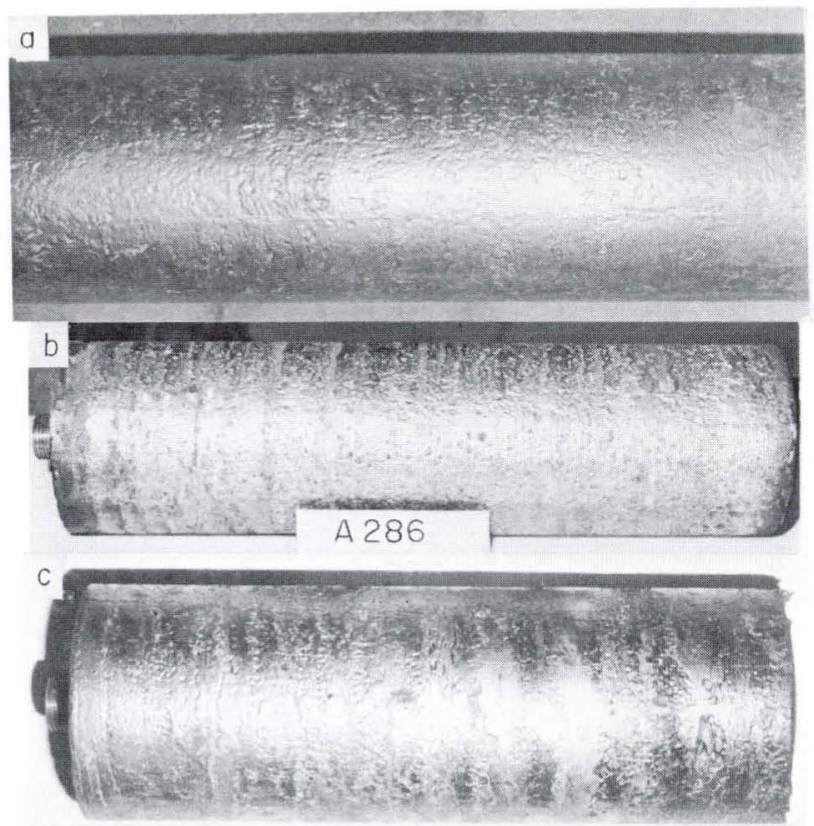
(a) INCO718 (I-2)
(b) A286 (A-2)
(c) $\mathrm{SUJ} 3(\mathrm{~J}-3)$

Photo. 1. Surface appearance of PPC remelted ingots ingot had the smoothest surface, which was nearly the same as that of the ESR ingot. The A286 and SUJ3 ingots had less smoothness, i.e., uneven surfaces. The stripes perpendicular to the growth direction of the ingot may be caused by the intermittent withdrawing of the ingot during remelting.

All the ingots remelted by PPG had no blowholes nor other defects just beneath the surface layer. Consequently, it was found that the surface appearance of the PPC ingots was dependent on the plasma power and that by the proper selection of the plasma power and remelting rate for the steel grades the ingot could be obtained with the smoother surface than the VAR ingots and nearly the same as that of the ESR ingots.

These ingots could be rolled or forged directly without turning or after slight grinding.

\section{Macrostructure}

The macrostructures of the PPC ingots remelted with $65 \mathrm{~kW}$ and $100 \mathrm{~kW}$ power, respectively, are shown in Photos. 2(a) and (b) and that of the VAR ingot (2 $700 \mathrm{~A}, 77 \mathrm{~kW})$ is shown in Photo. 2(c).

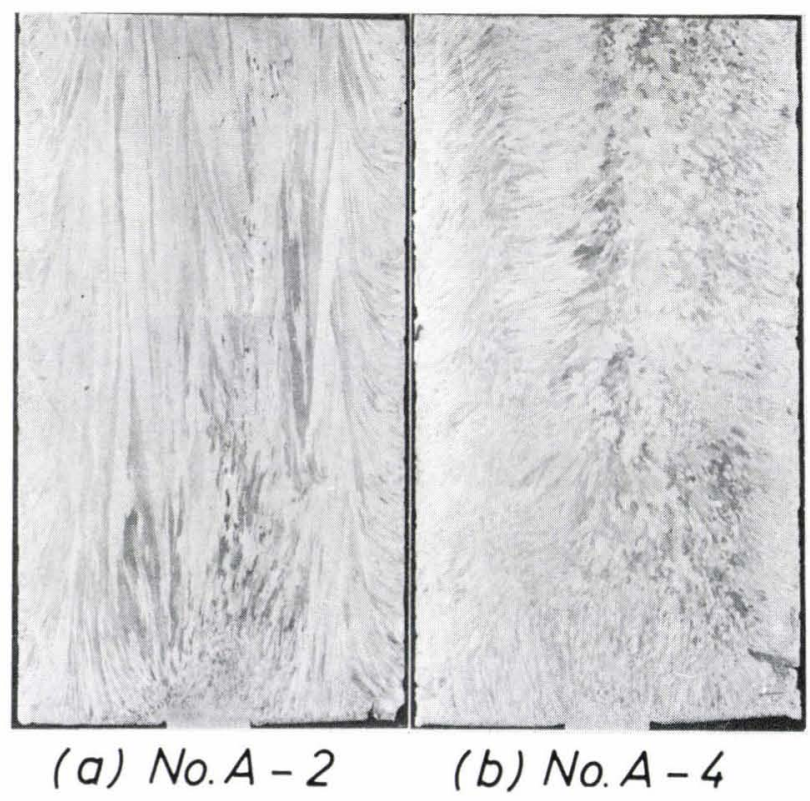

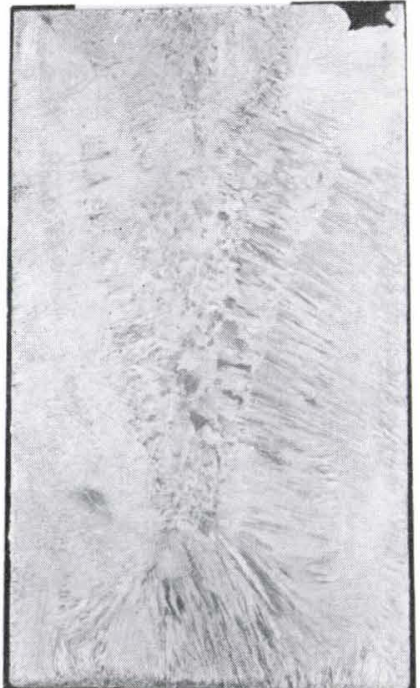

(c) No.A - 1
Photo. 2.

Macrostructure of PPC (a and b) and VAR (c) ingots of A286 alloy $(\times 1 / 2)(\times 4 / 5)$ 
These macropictures correspond to the bottom half of the PPC ingots, while that of the VAR ingot corresponds to that of the whole ingot. All macrostructures were obtained by electrolytic etching in 10\% $\mathrm{HCl}-\mathrm{Al}$ cohol solution. There is a distinct difference between the PPC and the VAR ingots. The most characteristic feature is the vertical growth of the columnar crystals in the PPC ingot remelted by the power of $65 \mathrm{~kW}$.

In the VAR ingot, the columnar crystals grew to the nearly horizontal direction and in the center of the ingot, there were the equiaxed crystals. However, in case of remelting with a relatively high power, the nearly horizontal columnar crystals and some equiaxed crystals grew even in the PPC ingots.

Consequently, because of the capability of controlling the plasma power and the melting rate independently in the $\mathrm{PPC}$ remelting, the solidification structure can be controlled to some extent: By selecting the low plasma power and the relatively slow melting rate, the directionally-solidified ingot could be obtained. The irregularity of the macrostructure of the PPC ingots seen in Photo. 2 would be resulted from the fluctuation of the plasma arc caused by the bending of the bars, and the same phenomena were caused also when the feeding speed of the bars was changed.

It is also considered from Photo. 2 that there might be the great difference in the mode of the solidification, i.e., in the shape and the size of the metal pool during remelting. The heat source of the PPG remelting was a plasma-arc-spot of the 20 to $30 \mathrm{~mm}$ diameter, and on the other hand that of the VAR was the wider arc from the consumable electrode of the $50 \mathrm{~mm}$ diameter. Furthermore, there was the difference in the melting rate, 15.6 to $28.6 \mathrm{~kg} / \mathrm{h}$ and $55 \mathrm{~kg} / \mathrm{h}$ for PPC and VAR, respectively. Therefore, these may cause the difference of the temperature distribution and so of the shape and the size of the metal pool between the two processes.
Judging from the relatively small arc spot, it could be expected that the metal pool in PPC might have the inhomogeneous temperature distribution and be deeper in the centre part. However, the macrostructure contrarily suggested that the depth of the metal pool of VAR was deeper than PPC. So the shape and the size of the metal pool were experimentally investigated.

\section{Shape of Metal Pool}

To examine the shape of the metal pool, the Fe-W alloy was added into the metal pool at the steadystate PPC remelting, and the plasma power was turned off. On the other hand, Fe-W alloy and $\mathrm{S}$ were buried simultaneously in a certain position of the consumable electrode of VAR, and just after the melting off of that position, the arc was turned off. The VAR conditions were $3500 \mathrm{~A}, 95 \mathrm{~kW}$ and $66 \mathrm{~kg} / \mathrm{h}$.

The SUJ3 ingots made by these methods were cut parallel to the growth direction and macroetched. As given in Table 3 , the $\mathrm{PPC}$ remelting was made with the plasma power of 65 and $85 \mathrm{~kW}$ and with the melting rate of 17 and $22 \mathrm{~kg} / \mathrm{h}$. The macrostructures of these ingots are shown in Photos. 3(a) to (d). The slope of the boundary line of the metal pool and the solidified shell was sharp near the ingot

Table 3. Conditions of PPC remelting for measurement of metal pool shape and maximum metal pool depth $\left(H_{\max }\right)$

\begin{tabular}{|c|c|c|c|c|c|}
\hline No. & $\begin{array}{c}\text { Power } \\
(\mathrm{kW})\end{array}$ & $\begin{array}{l}\text { Av. amp. } \\
\text { (A) }\end{array}$ & $\begin{array}{l}\text { Melt rate } \\
(\mathrm{kg} / \mathrm{h})\end{array}$ & $\begin{array}{c}\text { Ingot } \\
(\mathrm{mm}, \mathrm{kg})\end{array}$ & $\begin{array}{l}H_{\max } \\
(\mathrm{mm})\end{array}$ \\
\hline $\mathrm{a}$ & 65 & 1030 & 17.2 & $\begin{array}{c}107 \phi \times 220 \mathrm{~L} \\
15.5\end{array}$ & 20.4 \\
\hline $\mathrm{b}$ & 65 & 1030 & 22.1 & $\begin{array}{c}107 \dot{\phi} \times 218 \mathrm{~L} \\
15.4\end{array}$ & 27.0 \\
\hline $\mathrm{c}$ & 85 & 1300 & 16.1 & $\begin{array}{c}107 \dot{\phi} \times 240 \mathrm{~L} \\
17.2\end{array}$ & 25.8 \\
\hline d & 85 & 1300 & 22.5 & $\begin{array}{c}107 \phi \times 230 \mathrm{~L} \\
16.2\end{array}$ & 31.6 \\
\hline
\end{tabular}

\footnotetext{
* L : length
}

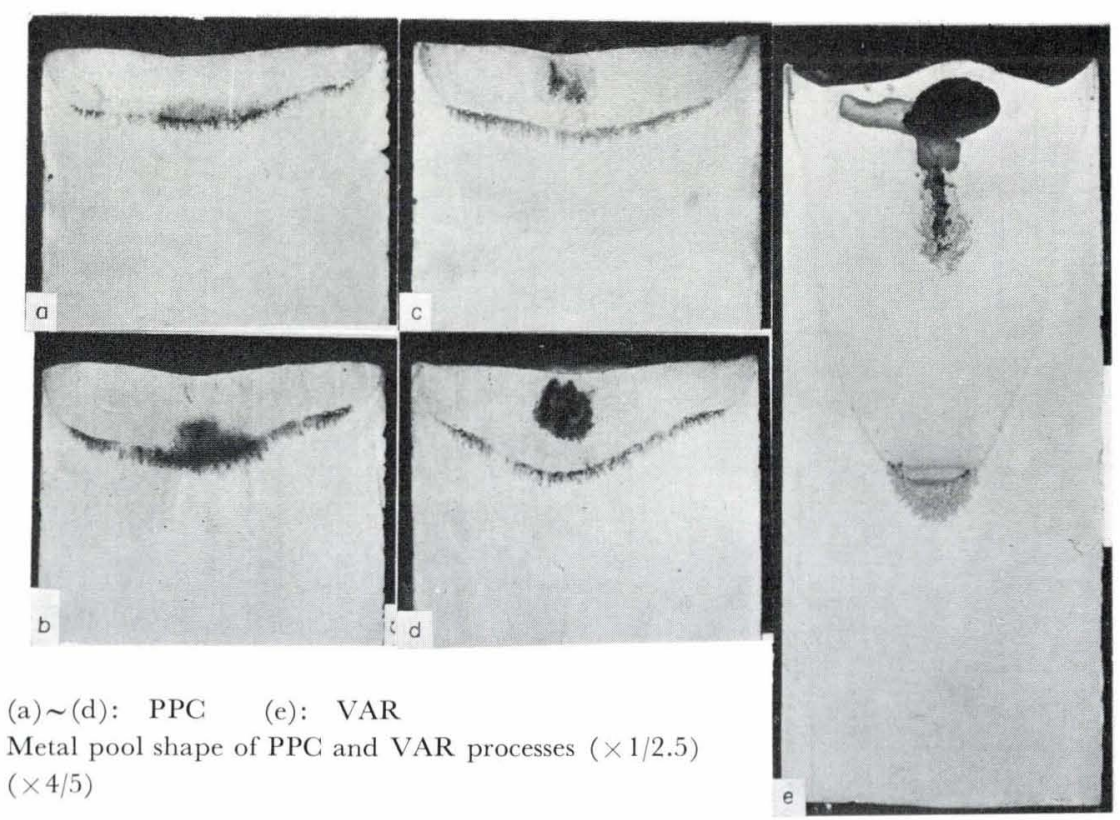

Photo. 3. Metal pool shape of PPC and VAR processes $(\times 1 / 2.5)$ $(\times 4 / 5)$ 
surface but in the inner part, it was very flat in PPC. The maximum pool depth, $H_{\max }$, were 20 to $31 \mathrm{~mm}$ which were $1 / 3.4$ to $1 / 5.2$ of the mould diameter.

On the other hand, the shape of the metal pool of VAR was very different from those of PPC, and the depth of the pool $\left(H_{\max }=135 \mathrm{~mm}\right)$ was larger than the mould diameter. It was also found that even in PPC, the lower the power and the slower the melting rate were, the flatter the pools were.

As the reason for these results, the followings are considered.

(1) In PPC, the remelting rate can be selected independently on the given plasma power. Thus, by selecting the melting rate slow, the pool can be obtained with homogeneous temperature distribution. In VAR, the melting rate is higher than PPC even under the same power, so that the pool is larger and deeper than PPC.

(2) It is known for VAR that the pool becomes deeper in proportion to the amperage. ${ }^{9)}$ This dependency could also be observed in PPC. However, even if the power is the same, the amperage of $\mathrm{PPC}$ is lower than VAR, because the voltage of PPC is higher than VAR. This may be the reason of the flat pool of PPC.

The reason for the perpendicular growth of the columnar crystals seen in Photo. 2(a) may be the flat pool seen in Photo. 3(a), which was remelted under almost the same conditions.

\section{Change of Chemical Compositions}

The chemical compositions of PPC and VAR ingots, and also of the bars are listed in Table 4 .

The change of the chemical compositions by remelting is generally dependent on the melting atmosphere. The atmosphere of VAR is $10^{-2}$ to $10^{-3}$ Torr and that of EBR is higher vacuum, so that the elements with high vapour pressures like Mn, Cr, etc. are inclined to be lost by vapourizing. In ESR under atmospheric pressure with slag, $\mathrm{Ti}, \mathrm{Al}$ and other reactive elements are inclined to be lost by oxidizing. So, it is considerably difficult to control the chemical compositions and to get a homogeneous ingot.

Meanwhile, the PPC remelting is carried out under a flow of Ar at $1 \mathrm{~atm}$. Thus, the vapourizing and oxidizing loss of those elements scarcely occur.

The results in Table 4 proved the characteristics of PPC described above, with no change of Ti, Al in INCO718, A286, and $\mathrm{Mn}$ in SUJ3. In VAR, manganese loss was seen in A286, SUJ3 having comparatively high manganese content.

The deoxidization by PPC was observed, although it was not observed on INCO718, because the raw material had very low oxygen content. This was also observed in VAR. Oxygen content of SUJ3 and SKDll, which had more than $1 \% \mathrm{C}$, was less than $10 \mathrm{ppm}$ after PPC. That of A286 containing $0.03 \% \mathrm{C}$ was relatively high, 14 to $18 \mathrm{ppm}$. This implies that the $\mathrm{C}-\mathrm{O}$ reaction is one of the deoxidizing mechanisms of the PPC remelting. The partial pressure of the $\mathrm{CO}$ gas $\left(P_{\mathrm{CO}}\right)$ in the atmosphere during remelting is estimated at most $0.01 \mathrm{mmHg}$. Because the fresh

Table 4. Chemical composition of ingots before remelting and after PPC

\begin{tabular}{|c|c|c|c|c|c|c|c|c|c|c|c|}
\hline Alloy & No. & $\mathrm{C}$ & $\mathrm{Si}$ & $\mathrm{Mn}$ & $\mathrm{P}$ & $\mathrm{S}$ & $\mathrm{Ni}$ & $\mathrm{Cr}$ & Mo & $\mathrm{Fe}$ & $\mathrm{Ti}$ \\
\hline \multirow{9}{*}{ INCO718 } & Before remelting (PI-VAR) & 0.046 & 0.19 & 0.10 & 0.003 & 0.001 & 53.1 & 18.9 & 3.0 & 17.8 & 1.05 \\
\hline & After VAR & 0.049 & 0.24 & 0.10 & 0.004 & 0.001 & 53.1 & 18.6 & 3.0 & 17.6 & 1.05 \\
\hline & After PPC & 0.047 & 0.21 & 0.10 & 0.004 & 0.001 & 53.1 & 19.0 & 3.0 & 17.8 & 1.07 \\
\hline & After PPC & 0.049 & 0.22 & 0.10 & 0.004 & 0.001 & 53.2 & 18.9 & 3.0 & 17.7 & 1.07 \\
\hline & Before remelting (PI) & 0.040 & 0.20 & 0.10 & 0.003 & 0.005 & 51.7 & 18.5 & 3.0 & 19.4 & 1.07 \\
\hline & After VAR & 0.040 & 0.18 & 0.09 & 0.003 & 0.005 & 51.8 & 18.5 & 3.0 & 19.6 & 1.06 \\
\hline & After PPG & 0.033 & 0.18 & 0.11 & 0.004 & 0.004 & 51.8 & 18.5 & 2.9 & 19.8 & 1.07 \\
\hline & After PPC & 0.037 & 0.19 & 0.11 & 0.002 & 0.004 & 51.6 & 18.5 & 3.0 & 19.7 & 1.06 \\
\hline & After PPC & 0.036 & 0.19 & 0.10 & 0.002 & 0.005 & 51.7 & 18.5 & 2.8 & 19.4 & 1.09 \\
\hline \multirow{4}{*}{ A286 } & Before remelting (PI) & 0.029 & 0.48 & 1.45 & 0.011 & 0.008 & 25.5 & 14.9 & 1.2 & bal. & 2.2 \\
\hline & After VAR & 0.027 & 0.49 & 1.41 & 0.011 & 0.007 & 25.5 & 15.0 & 1.2 & bal. & 2.2 \\
\hline & After PPC & 0.027 & 0.50 & 1.49 & 0.010 & 0.008 & 25.5 & 14.8 & 1.3 & bal. & 2.2 \\
\hline & After PPC & 0.026 & 0.51 & 1.47 & 0.010 & 0.008 & 25.4 & 14.9 & 1.3 & bal. & 2.2 \\
\hline \multirow{5}{*}{ SUJ3 } & Before remelting (AF-Degas) & 1.00 & 0.51 & 1.01 & 0.015 & 0.008 & 0.05 & 1.00 & - & bal. & - \\
\hline & After VAR & 0.99 & 0.49 & 0.99 & 0.015 & 0.008 & 0.05 & 1.02 & - & bal. & - \\
\hline & After PPC & 0.98 & 0.49 & 1.01 & 0.017 & 0.008 & 0.05 & 1.01 & - & bal. & - \\
\hline & After PPC & 0.99 & 0.52 & 1.01 & 0.015 & 0.008 & 0.05 & 0.99 & - & bal. & - \\
\hline & After PPC & 0.98 & 0.46 & 1.01 & 0.013 & 0.008 & 0.06 & 1.01 & - & bal. & - \\
\hline \multirow{4}{*}{ SKD11 } & Before remelting (IF) & 1.53 & 0.28 & 0.43 & 0.016 & 0.017 & 0.07 & 12.00 & 0.97 & bal. & - \\
\hline & After VAR & 1.50 & 0.30 & 0.42 & 0.015 & 0.017 & 0.07 & 12.00 & 0.99 & bal. & - \\
\hline & After PPC & 1.51 & 0.31 & 0.45 & 0.014 & 0.017 & 0.06 & 11.88 & 0.98 & bal. & - \\
\hline & After PPC & 1.56 & 0.30 & 0.45 & 0.018 & 0.018 & 0.07 & 12.14 & 0.98 & bal. & - \\
\hline
\end{tabular}


Ar (99.999\%) always flows during remelting, the equilibrium oxygen content for this $P_{\mathrm{CO}}$ of the steels containing $\mathrm{C}$ more than $0.03 \%$ is the order of $10^{-5} \%$, and so, it is very probable that the $\mathrm{C}-\mathrm{O}$ deoxidization would take place.

As the mechanism of the deoxidization during $\mathrm{PPC}$, the removal of the oxide inclusions can be also considered, as described below. The removal of $\mathrm{N}$, $\mathrm{P}$ and $\mathrm{S}$ was not observed.

\section{Morphological Change of Oxide Inclusions}

The quality of the ball bearing steel, SUJ3, is affected more by the oxide inclusions. So, the morphological change of the oxide inclusions by remelting was examined. The measurements were made on the bars fed to remelt and on the remelted-20 $\mathrm{mm} \phi$ forged bars.

The characteristic oxide inclusions in these steels are shown in Photo. 4. The oxide inclusions of the PPC and VAR ingots change to smaller than those of the bars fed to remelt and change to the oxy-sulphide inclusions. The cleanliness determined by JIS method is shown in Table 5. The area percentage of the oxide inclusions ( $d C$ in Table 5 ) of the remelted bars were less than the initial bars, which was most clearly seen in the heat of $\mathrm{J}-4$ remelted by PPC.

These results were also expected from the oxygen analysis. It is generally recognized that the large oxide inclusions are most detrimental for the rolling fatigue life of SUJ3, while the oxide inclusions smaller than the critical size are not so detrimental. Therefore, it is important in remelting to get the steels with

or VAR

\begin{tabular}{|c|c|c|c|c|c|}
\hline sol. Al & ins. $\mathrm{Al}$ & $\mathrm{N}$ & $\mathrm{O}$ & \multicolumn{2}{|c|}{ Others } \\
\hline 0.57 & $<0.002$ & 0.003 & 0.0009 & $\mathrm{Nb}+\mathrm{Ta}: 5.1$ & B : 0.003 \\
\hline 0.52 & 0.002 & 0.007 & 0.0012 & $\mathrm{Nb}+\mathrm{Ta}: 5.2$ & B : 0.004 \\
\hline 0.56 & 0.002 & 0.003 & 0.0020 & $\mathrm{Nb}+\mathrm{Ta}: 5.1$ & B : 0.005 \\
\hline 0.55 & $<0.002$ & 0.007 & 0.0007 & $\mathrm{Nb}+\mathrm{Ta}: 5.2$ & B : 0.004 \\
\hline 0.63 & 0.010 & 0.029 & 0.0027 & $\mathrm{Nb}+\mathrm{Ta}: 4.8$ & B : 0.003 \\
\hline 0.67 & 0.008 & 0.035 & 0.0023 & $\mathrm{Nb}+\mathrm{Ta}: 4.9$ & B : 0.003 \\
\hline 0.63 & 0.004 & 0.025 & 0.0021 & $\mathrm{Nb}+\mathrm{Ta}: 4.6$ & B : 0.003 \\
\hline 0.65 & 0.005 & 0.032 & 0.0024 & $\mathrm{Nb}+\mathrm{Ta}: 4.9$ & B : 0.003 \\
\hline 0.63 & 0.004 & 0.024 & 0.0026 & $\mathrm{Nb}+\mathrm{Ta}: 5.0$ & B : 0.003 \\
\hline 0.33 & 0.004 & 0.005 & 0.0062 & $V: 0.26$ & B : 0.008 \\
\hline 0.33 & 0.002 & 0.006 & 0.0019 & $\mathrm{~V}: 0.25$ & B : 0.006 \\
\hline 0.31 & 0.002 & 0.005 & 0.0014 & $V: 0.25$ & B : 0.007 \\
\hline 0.33 & 0.002 & 0.006 & 0.0017 & $V: 0.25$ & B : 0.007 \\
\hline 0.31 & 0.003 & 0.004 & 0.0018 & $\mathrm{~V}: 0.26$ & B : 0.007 \\
\hline 0.05 & 0.002 & 0.007 & 0.0020 & & \\
\hline 0.05 & $<0.002$ & 0.006 & 0.0008 & & \\
\hline 0.05 & $<0.002$ & 0.006 & 0.0008 & & \\
\hline 0.05 & $<0.002$ & 0.007 & 0.0008 & & \\
\hline 0.05 & $<0.002$ & 0.006 & 0.0007 & & \\
\hline$<0.002$ & $<0.002$ & 0.024 & 0.0057 & $V: 0.41$ & \\
\hline$<0.002$ & $<0.002$ & 0.023 & 0.0008 & $V: 0.38$ & \\
\hline$<0.002$ & $<0.002$ & 0.024 & 0.0009 & $V: 0.40$ & \\
\hline$<0.002$ & $<0.002$ & 0.025 & 0.0006 & $V: 0.41$ & \\
\hline$<0.002$ & $<0.002$ & 0.025 & 0.0009 & $V: 0.40$ & \\
\hline
\end{tabular}

finely distributed smaller oxides, as well as to reduce these. There are some literatures on the critical size $^{10)}$ to be 5 to $10 \mu \mathrm{m}$. Table 6 shows the size distribution of the oxide inclusions measured by the optical microscope. It is clearly seen that the oxide inclusions after remelting became smaller than before, and especially the larger ones than $8 \mu \mathrm{m}$ became fewer. In the heat J-4, both small and large oxide inclusions were the fewest, corresponding to the area percentage in Table 5.

On the other hand, the compositional change of the oxide inclusions were examined by EPMA and isolating method by the hot-sulphuric acid. By EPMA measurement, $\mathrm{Al}$ was detected most strongly and $\mathrm{Ca}$, $\mathrm{Mg}$ detected weakly. No differences were detected during the heats.

Table 7 on the results of the isolating method shows that the oxide inclusions were only $\mathrm{Al}_{2} \mathrm{O}_{3}$ and the oxide inclusions were reduced by remelting but no compositional change was found. Consequently, the composition of the oxide inclusions by remelting did not change as known in the literature. ${ }^{11)}$ These results suggested the floating out of the oxide inclusions as the mechanism of the deoxidization. That is, the larger oxides floated out during remelting and only the smaller ones remained in the remelted ingot, and consequently the total oxygen content was reduced.

From the fewest oxide inclusions in the heat $\mathrm{J}-4$, the higher temperature of the metal drops and the metal pool, the smaller viscosity of the molten metal resulting from the higher plasma power and the unidirectional solidification pattern can be advantageous for the oxide inclusions to float out.

\section{Quality of Plasma Arc Remelted Steels}

\section{Hot Workability}

INCO718 and A286 are respectively the Ni-base and the Fe-base superalloys. It is known that their hot workability are rather bad. The product cost of these superalloys is largely affected by the yield of hot working. The superalloys are generally produced by remelting. This may be because remelting improves the solidification structure with better hot workability.

The hot workability of the PPC ingots was examined by the Gleeble testing machine. These tests were made by the test pieces, $6.35 \mathrm{~mm} \phi \times 110 \mathrm{mmL}$, sampled vertically from the vertically growing columnar position, $15 \mathrm{~mm}$ beneath the ingot surface, of the bottom half of the PPG or VAR ingots. The test conditions were as follows; time to the test temperature $100 \mathrm{sec}$, holding time $60 \mathrm{sec}$, strain rate $2 \mathrm{in} / \mathrm{sec}$, and test temperature $1025^{\circ}$ to $150^{\circ} \mathrm{C}$. The results are shown in Figs. 2 and 3.

The temperature dependency of the reduction of area of the PPC remelted INCO718 was similar to that of VAR, but the values were about $10 \%$ larger at all test temperature. On the other hand, in A286 the reduction of area of the PPC ingot was large in the wider temperature range than that of VAR, and the values were 30 to $40 \%$ larger.

From these results, it may be concluded that the hot workability of the ingots can be improved by the 


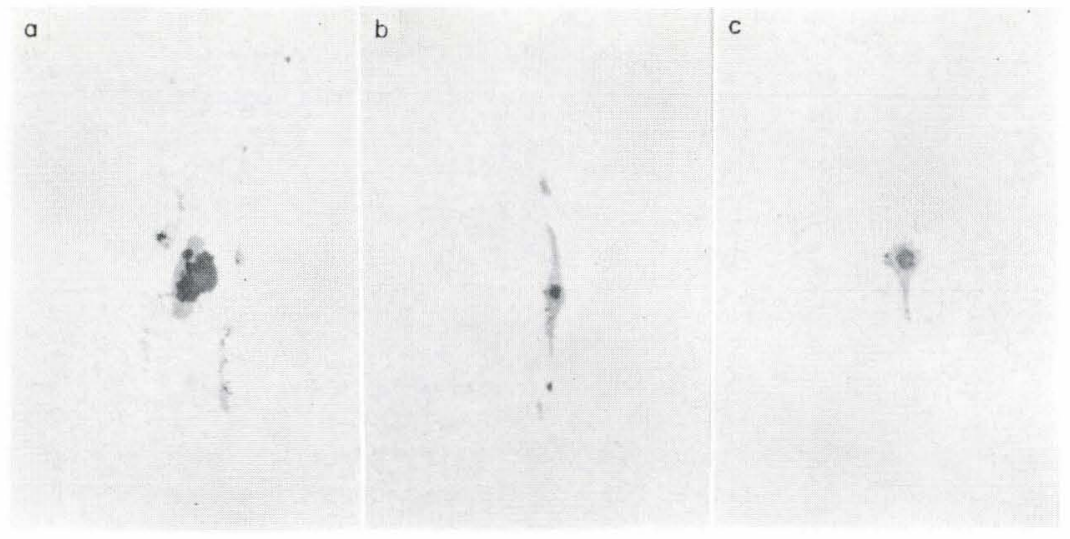
(a) before remelting
(b) after PPC (J-4)
(c) after $\operatorname{VAR}(\mathrm{J}-1)$

Photo. 4. Oxide inclusions in SUJ3 $(\times 400)$ $(\times 9 / 10)$
Table 5. Cleanliness of SUJ3 by JIS method

\begin{tabular}{cl|cccc}
\hline & & $d$ & $d A$ & $d B$ & $d C$ \\
\hline Before remelting & 0.052 & 0.038 & 0 & 0.014 \\
\hline J-1 & (VAR) & 0.041 & 0.033 & 0 & 0.008 \\
J-2 & (PPC) & 0.049 & 0.038 & 0 & 0.011 \\
J-3 & (PPC) & 0.041 & 0.035 & 0 & 0.006 \\
J-4 & (PPC) & 0.038 & 0.034 & 0 & 0.004 \\
\hline
\end{tabular}

Table 6. Size distribution of oxide inclusions (SUJ3)

\begin{tabular}{|c|c|c|c|c|c|c|}
\hline$(\mu)$ & $\begin{array}{l}>2 \\
\leq 4\end{array}$ & $\begin{array}{l}>4 \\
\leq 6\end{array}$ & $\begin{array}{l}>6 \\
\leq 8\end{array}$ & $\begin{array}{r}>8 \\
\leq 10\end{array}$ & $\begin{array}{l}>10 \\
\leq 12\end{array}$ & $\begin{array}{l}>12 \\
\leq 14\end{array}$ \\
\hline Before remelting & 46.0 & 28.4 & 11.4 & 6.8 & 1.7 & 0.6 \\
\hline $\mathrm{J}-1$ (VAR) & 48.2 & 33.9 & 7.7 & 1.8 & 0.6 & 0 \\
\hline (PPC) & 49.3 & 34.8 & 11.6 & 2.2 & 0.7 & 0 \\
\hline (PPC) & 36.0 & 12.0 & 3.0 & 0 & 0 & 0 \\
\hline $\mathrm{J}-4 \quad$ (PPG) & 27.1 & 4.5 & 3.0 & 0 & 0.8 & 0 \\
\hline
\end{tabular}

Number $/ 100 \mathrm{~mm}^{2}$, Field of view : $150 \mathrm{~mm}^{2}$

Table 7. Composition of separated oxide inclusions in SUJ3

\begin{tabular}{|c|c|c|}
\hline & \multicolumn{2}{|c|}{ Amount (ppm) } \\
\hline & $\mathrm{Al}_{2} \mathrm{O}_{3}$ & $\mathrm{SiO}_{2}$ \\
\hline Before remelting & 13 & $<5$ \\
\hline $\mathrm{J}-1 \quad$ (VAR) & 6 & $<5$ \\
\hline $\mathrm{J}-2 \quad$ (PPC) & 8 & $<5$ \\
\hline $\mathrm{J}-3 \quad$ (PPC) & 9 & $<5$ \\
\hline $\mathrm{J}-4 \quad$ (PPC) & 9 & $<5$ \\
\hline
\end{tabular}

Dissolving solution: $\mathrm{H}_{2} \mathrm{SO}_{4}: \mathrm{H}_{2} \mathrm{O}=1: 4$

vertically-growing columnar crystals.

\section{Distribution of Alloying Elements}

The distribution of alloying elements in the PPC ingots was compared with that of VAR. The samples for analysing were drilled from the as-cast ingots, using bottom half of the PPC ingot and the whole VAR ingot. Each ingot was divided into four sections to the vertical direction $\left(\mathrm{T} \rightarrow \mathrm{M}_{1} \rightarrow \mathrm{M}_{2} \rightarrow \mathrm{B}\right)$ and each section was further divided to three partscentre, $1 / 2$ centre and outerside-namely at $10 \mathrm{~mm}$ beneath the ingot surface.

The distribution of $\mathrm{Ti}, \mathrm{Al}$ in the INCO718 and

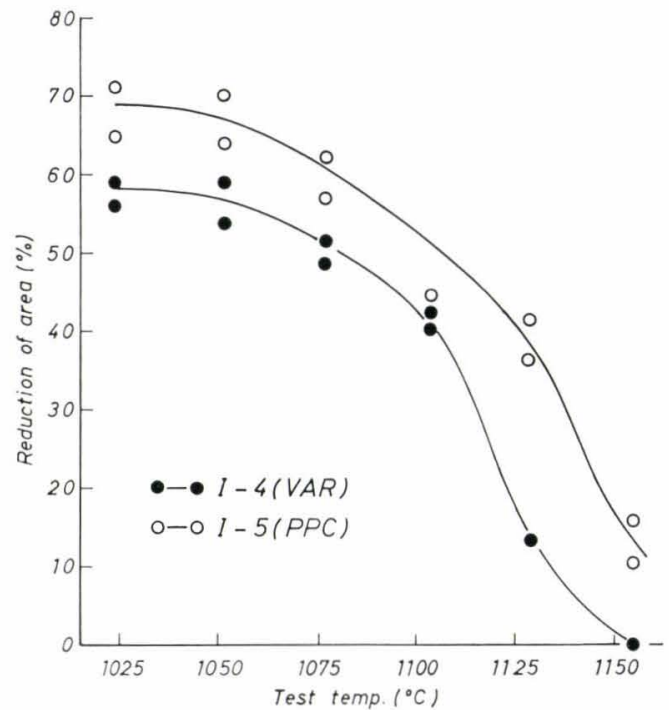

Fig. 2. Hot ductility of INCO718 alloy ingots after PPC and VAR

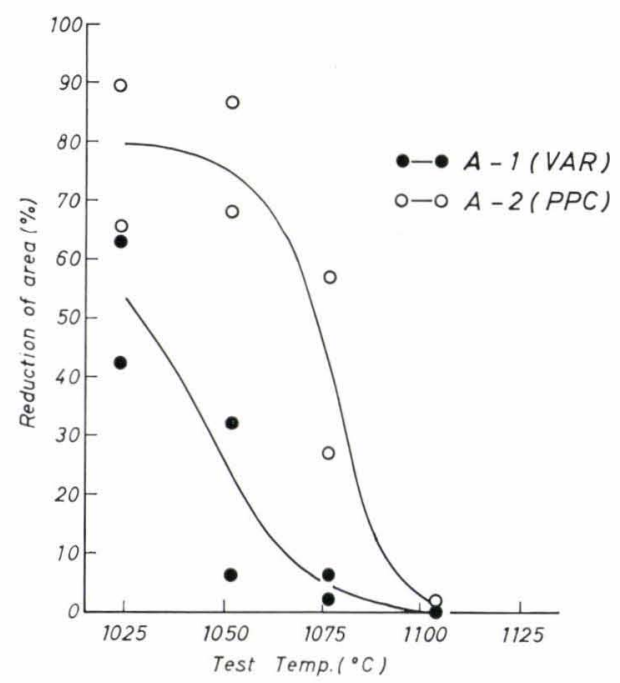

Fig. 3. Hot ductility of A286 alloy ingots after PPC and VAR

in the A286 ingots and of Mn, $\mathrm{Cr}$ in the SUJ3 ingots are shown in Figs. 4 to 7 . Those of $\mathrm{Mn}$ and $\mathrm{Cr}$ fluctuated largely among the examined elements. The fluctuations of $\mathrm{Ti}, \mathrm{Al}$ in the PPC and the VAR ingots were both a little larger than those of $\mathrm{Mn}$ and Cr. The manganese content of the VAR ingot was 


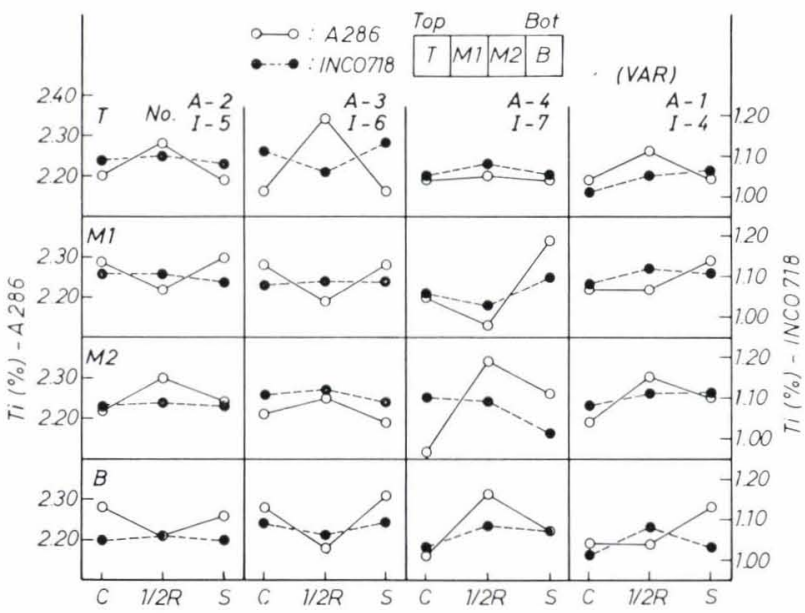

Fig. 4. Distribution of Ti in A286 and INCO718 ingots remelted by $\mathrm{PPC}$ or VAR

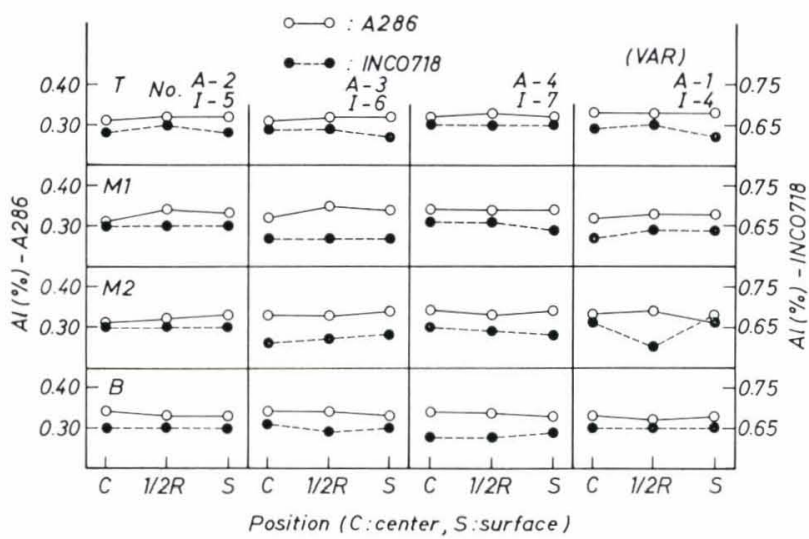

Fig. 5. Distribution of $\mathrm{A} 1$ in $\mathrm{A} 286$ and $\mathrm{INCO} 718$ ingots remelted by PPC or VAR

relatively low in the top.

Consequently, the distribution of the alloying elements in the PPC and the VAR ingot was almost the same and there was no problem.

\section{Mechanical Properties}

The mechanical properties at room and high temperatures and the stress rupture of INCO718 and A286 were examined. The test pieces were machined from the $20 \mathrm{~mm} \phi$ forged bars. The test results are shown in Tables 8 to 11. The stress rupture tests of each heat were made twice, and Tables 9 and 11 show the two data. These results of the PPC and the VAR ingots were almost the same and satisfied the required properties.

\section{Conclusions}

The feature of plasma-arc remelting and the quality of the plasma-arc-remelted steels and superalloys were investigated by using an originally designed PPC (Plasma Progressive Casting) furnace with a watercooled copper mould of $110 \mathrm{~mm}$ diameter.

The results obtained were as follows:

(1) In PPC remelting, it was possible to control the solidification structure of the ingot. It was found that a relatively slow melting rate with a given plasma power resulted in a very shallow metal pool. Thus,

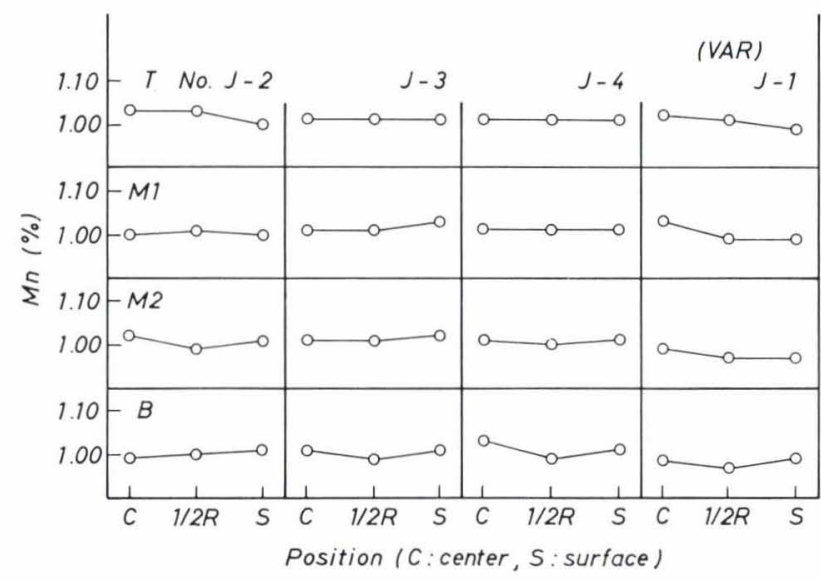

Fig. 6. Distribution of $\mathrm{Mn}$ in $\mathrm{SUJ} 3$ ingot remelted by $\mathrm{PPC}$ or VAR

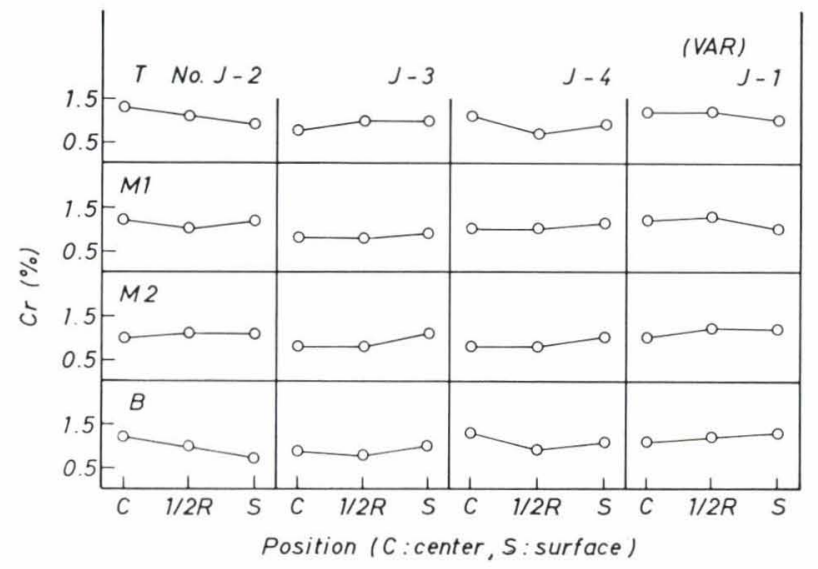

Fig. 7. Distribution of $\mathrm{Cr}$ in SUJ3 ingot remelted by PPC or VAR

the unidirectionally-solidified ingot was obtained with the vertical columnar crystals.

(2) It was also found that the hot workability of a solidification-controlled PPC ingot with the vertical columnar crystals was superior to that of the VAR ingot.

(3) No chemical composition change including for $\mathrm{Ti}, \mathrm{Al}, \mathrm{Mn}$, etc., which sometimes change during other remelting processes, was observed. Deoxidization could be done in the PPC process. The $\mathrm{C}-\mathrm{O}$ reaction and the removal of the $\mathrm{Al}_{2} \mathrm{O}_{3}$-type oxide inclusions were suggested for the deoxidization mechanism.

(4) The surface appearance of the PPC remelted ingot was comparable to that of the ESR ingot, though some differences were observed between the steel grades.

(5) The distribution of the alloying elements in a PPC ingot and the mechanical properties were almost the same as those of the VAR ingot.

As described above, the plasma-arc remelting contributes to various improvements. However, these results were all obtained by the experimental small scale furnace, so that the cost aspects could not be fully discussed. However, by the improvement of the construction of the furnace and the operation method, it may be possible to scale up and industrialize this process in near future. 
Table 8. Mechanical properties of INCO718 bars forged directly from ingot (Solution treated and aged)

\begin{tabular}{|c|c|c|c|c|c|c|c|c|}
\hline \multicolumn{2}{|c|}{ Heat No. } & \multirow{2}{*}{$\begin{array}{c}\begin{array}{c}\text { Temp. } \\
\left({ }^{\circ} \mathrm{C}\right)\end{array} \\
\text { Room temp. }\end{array}$} & \multirow{2}{*}{$\begin{array}{c}\begin{array}{c}0.02 \% \mathrm{YS} \\
\left(\mathrm{kg} / \mathrm{mm}^{2}\right)\end{array} \\
-\end{array}$} & \multirow{2}{*}{$\begin{array}{c}\begin{array}{c}0.2 \% \mathrm{YS} \\
\left(\mathrm{kg} / \mathrm{mm}^{2}\right)\end{array} \\
120.9\end{array}$} & \multirow{2}{*}{$\begin{array}{c}\begin{array}{c}\text { UTS } \\
\left(\mathrm{kg} / \mathrm{mm}^{2}\right)\end{array} \\
147.0\end{array}$} & \multirow{2}{*}{$\begin{array}{c}\% \text { EL } \\
19.1\end{array}$} & \multirow{2}{*}{$\begin{array}{l}\% \text { RA } \\
39.2\end{array}$} & \multirow{2}{*}{$\begin{array}{c}\begin{array}{c}\text { Hard } \\
(\mathrm{Rc})\end{array} \\
44\end{array}$} \\
\hline I-1 & $(\mathrm{VAR})$ & & & & & & & \\
\hline $\mathrm{I}-2$ & $(\mathrm{PPC})$ & Room temp. & - & 124.2 & 132.6 & 17.5 & 38.1 & 43 \\
\hline I-3 & $(\mathrm{PPC})$ & Room temp. & - & 130.4 & 150.8 & 15.6 & 36.8 & 43 \\
\hline $\mathrm{I}-4$ & (VAR) & Room temp. & 95.3 & 114.5 & 141.1 & 22.0 & 32.2 & 44 \\
\hline $\mathrm{I}-5$ & (PPC) & Room temp. & 92.4 & 106.3 & 137.7 & 21.4 & 27.6 & 43 \\
\hline I-6 & (PPC) & Room temp. & 84.1 & 106.4 & 137.5 & 20.1 & 29.3 & 42 \\
\hline $\mathrm{I}-7$ & (PPC) & Room temp. & 89.3 & 107.4 & 136.1 & 22.3 & 32.6 & 42 \\
\hline I-1 & (VAR) & 649 & - & 100.3 & 117.1 & 21.9 & 36.4 & 43 \\
\hline I-2 & (PPC) & 649 & - & 103.3 & 121.5 & 24.2 & 47.1 & 43 \\
\hline I-3 & (PPC) & 649 & - & 108.7 & 123.7 & 16.5 & 26.4 & 45 \\
\hline $\mathrm{I}-4$ & (VAR) & 649 & 81.2 & 95.9 & 117.2 & 19.2 & 39.1 & 43 \\
\hline $\mathrm{I}-5$ & (PPC) & 649 & 76.7 & 90.4 & 113.6 & 14.9 & 22.6 & 43 \\
\hline$I-6$ & (PPC) & 649 & 79.3 & 94.1 & 117.0 & 17.1 & 23.4 & 43 \\
\hline I-7 & (PPC) & 649 & 73.7 & 90.1 & 112.8 & 18.5 & 32.7 & 43 \\
\hline
\end{tabular}

Solution treatment: $954^{\circ} \mathrm{C} \times 1 \mathrm{~h} \longrightarrow \mathrm{AC}$

Aging : $\quad 718^{\circ} \mathrm{C} \times 8 \mathrm{~h} \underset{56^{\circ} \mathrm{C} / \mathrm{h}}{\longrightarrow} 621^{\circ} \mathrm{C} \times 8 \mathrm{~h} \longrightarrow \mathrm{AC}$

Table 9. Results of stress rupture test (combination type) of INCO718 bars forged directly from ingot (Solution treated and aged)

\begin{tabular}{cl|ccccc}
\hline \multicolumn{2}{c|}{ Heat No. } & $\begin{array}{c}\text { Temp. } \\
\left({ }^{\circ} \mathrm{C}\right)\end{array}$ & $\begin{array}{c}\text { Stress } \\
\left(\mathrm{kg} / \mathrm{mm}^{2}\right)\end{array}$ & $\begin{array}{c}\text { Life } \\
(\mathrm{h})\end{array}$ & \%EL & $\%$ RA \\
\hline I-1 & (VAR) & 649 & 77.3 & $59.0 \sim 99.4$ & $25.9 \sim 17.4$ & $35.1 \sim 23.0$ \\
I-2 & (PPC) & 649 & 77.3 & $60.2 \sim 99.8$ & $15.2 \sim 34.2$ & $25.8 \sim 46.7$ \\
I-3 & (PPC) & 649 & 77.3 & $55.6 \sim 63.7$ & $22.0 \sim 25.3$ & $42.4 \sim 45.7$ \\
\hline I-4 & (VAR) & 649 & 70.3 & $66.5 \sim 122.1$ & $15.7 \sim 15.8$ & $29.7 \sim 33.0$ \\
I-5 & (PPC) & 649 & 70.3 & $121.3 \sim 140.4$ & $10.8 \sim 18.1$ & $12.3 \sim 26.5$ \\
I-6 & (PPC) & 649 & 70.3 & $65.7 \sim 140.1$ & $11.1 \sim 16.1$ & $23.4 \sim 24.1$ \\
I-7 & (PPC) & 649 & 70.3 & $62.8 \sim 122.3$ & $11.6 \sim 12.9$ & $17.8 \sim 26.9$ \\
\hline
\end{tabular}

Table 10. Mechanical properties of A286 bars forged directly from ingot (Solution treated and aged)

\begin{tabular}{|c|c|c|c|c|c|c|c|}
\hline Heat & No. & $\begin{array}{l}\text { Temp. } \\
\left({ }^{\circ} \mathrm{C}\right)\end{array}$ & $\begin{array}{l}0.02 \% \mathrm{YS} \\
(\mathrm{kg} / \mathrm{mm})^{2}\end{array}$ & $\begin{array}{c}0.2 \% \mathrm{YS} \\
\left(\mathrm{kg} / \mathrm{mm}^{2}\right)\end{array}$ & $\begin{array}{c}\text { UTS } \\
\left(\mathrm{kg} / \mathrm{mm}^{2}\right)\end{array}$ & $\%$ EL & $\% \mathrm{RA}$ \\
\hline A-1 & (VAR) & Room temp. & 60.4 & 70.7 & 115.9 & 29.1 & 46.2 \\
\hline A-2 & $(\mathrm{PPC})$ & Room temp. & 59.9 & 72.0 & 114.0 & 29.7 & 46.0 \\
\hline A-3 & $(\mathrm{PPC})$ & Room temp. & 59.2 & 71.9 & 115.4 & 28.3 & 48.1 \\
\hline A- 4 & (PPC) & Room temp. & 61.4 & 74.0 & 117.9 & 27.2 & 46.2 \\
\hline A-1 & (VAR) & 700 & 41.6 & 61.8 & 77.8 & 28.7 & 50.3 \\
\hline A-2 & (PPC) & 700 & 46.3 & 62.7 & 77.3 & 32.0 & 55.7 \\
\hline A-3 & (PPC) & 700 & 48.2 & 62.7 & 77.4 & 27.1 & 42.9 \\
\hline A-4 & (PPC) & 700 & 46.9 & 63.5 & 78.1 & 30.1 & 50.9 \\
\hline
\end{tabular}

Solution treatment: $982^{\circ} \mathrm{C} \times 1 \mathrm{~h} \longrightarrow \mathrm{OQ}$

Aging: $\quad 718^{\circ} \mathrm{C} \times 16 \mathrm{~h} \longrightarrow \mathrm{AC}$

Table 11. Results of stress rupture test (combination type) of A286 bars forged directly from ingot (Solution treated and aged)

\begin{tabular}{cl|ccccc}
\hline \multicolumn{2}{c|}{ Heat No. } & $\begin{array}{c}\text { Temp. } \\
\left({ }^{\circ} \mathrm{C}\right)\end{array}$ & $\begin{array}{c}\text { Stress } \\
\left(\mathrm{kg} / \mathrm{mm}^{2}\right)\end{array}$ & $\begin{array}{c}\text { Life } \\
(\mathrm{h})\end{array}$ & \%EL & \%RA \\
\hline A-1 & (VAR) & 649 & 45.7 & $183.7 \sim 235.5$ & $7.7 \sim 4.0$ & $13.5 \sim 9.9$ \\
A-2 & (PPC) & 649 & 45.7 & $320.5 \sim 329.6$ & $6.9 \sim 5.7$ & $11.1 \sim 13.0$ \\
A-3 & (PPC) & 649 & 45.7 & $219.9 \sim 245.0$ & $4.1 \sim 6.9$ & $8.7 \sim 11.2$ \\
A-4 & (PPC) & 649 & 45.7 & $312.2 \sim 354.3$ & $4.1 \sim 4.5$ & $8.8 \sim 7.1$ \\
\hline
\end{tabular}




\section{REFERENCES}

1) G. K. Bhat: Indust. Heat., (1975), June, 28.

2) W. F. Marley, Jr. and J. R. Wamsley: Metal Prog., (1976), April, 46.

3) H. O. Rossner: Stahl u. Eisen, 95 (1975), 61.

4) B. E. Paton, V. I. Lakomski, G. E. Torkhov and V. I. Piliptchuk: Proc. 3rd International Symposium on Electroslag and Other Special Melting Technology, Pittsburgh, June, 1971.

5) H. Förster: "Electron Guns and Their Application in the Electron Beam Technology", Memorial Lecutre on Electron Beam in DDR, ULVAC Corp. and Ataka \& Co., Ltd., Tokyo, May 15, 1975.

6) U. Chandra, J. Hartwig and K. H. Ulrich: Techn. Mitt.
Krupp Forsch. Ber., 31 (1973), H. 1, 1.

7) Yu. A. Bashnin, E. V. Verkhovsev, L. G. Chernukha and E. S. Yakimenko: Steel in USSR, (1975), 523.

8) V. V. Lempitskii, G. N. Okorokov and V. A. Boyarshinov: Steel in USSR, (1972), 203.

9) K. Bungardt and H. Vollmer: Stahl u. Eisen, 82 (1962), 401 .

10) e.g., K. Okamoto and S. Shiko: Seitetsu Kenkyu, (1971), No. $273,108$.

11) D. Ya. Povolotskii, V. E. Roshchin, A. V. Rechkalova and R. I. Grechin: Steel in USSR, (1974), 296.

12) H. Noda, C. Asada, I. Eguchi, T. Adachi and K. Hayashi: Electric Furnace Steel, 14 (1970), 267. 